\title{
Need Forensic Management in the Business Sectors of Developing Countries: Benefits and Strategies
}

\author{
Kingsley Akarowhe* \\ Department of Educational Foundations, Guidance and Counseling, University of Uyo, Nigeria
}

Submission: March 23, 2018; Published: April 26, 2018

"Corresponding author: Kingsley Akarowhe, Department of Educational Foundations, Guidance and Counselling, University of Uyo, Nigeria,

Email: kingsmith1172@gmail.com

\begin{abstract}
In less developed, developing and developed countries of the world, every sector of the economy innovates new strategies/approach/practices in the way and manner at which they carry out their daily affairs for improve productivity on the aggregate. The business sector, in developing countries inspite of its pertinent role of contributing to national development and economic growth, is faced with on-going techniques/strategies/ practices of management which often seems to yield little result in terms of aggregate productivity. These on-going techniques/strategies/ practices seem to be highly cost effective and less emphasis is placed on handling fraudulent activities in the course of managing a business in the business sector. It is due to this fact the researcher innovated the need for forensic management in the business sectors of developing countries. Forensic management is aimed at adopting a managerial approach in tackling misappropriation, mismanagement, embezzlement of funds and other fraudulent related issues in a given business sector, with a resultant high level of productivity in the business sector.

It is geared toward inculcating forensic method in the process of managing a given business. The paper explained the concept of forensic management, business sector; developing countries; it went further to discuss the benefits of forensic management - fraud detection, strong internal control, reduction in cost, bridging communication gap, and efficiency in management; and strategies for effective forensic management in the business sectors of developing countries - education, forensic management system, proper remuneration of employees and partnership/ collaboration. It was recommended among others that information communication technologies should be adopted in each individualized business and utilized in the day-to-day business activities, which will assist in fast-tracking cases of fraud or other financial related problems that might arise in the day-to-day business activity.
\end{abstract}

Keywords: Developing Countries; Business Sector; Forensic Management; Forensic; Management

\section{Introduction}

The study was exploratory and depends exclusively on secondary data. These secondary data are information from previous researchers on various concepts on the topic.

\section{Concept of Developing Countries}

Development is generically refers to an institutional change which is accompanied by increase in welfare, and fall in cost of living. In other word it is a reduction in unemployment, tribal inequality and poverty for a given nation [1]. It can also be seen as the later stage of growth [1]. Development is term used to describe a nation reduction in its level dependence on aids (financial, monetary, military and administrative) from other countries. According to [2] development is a process by which a high degree of self-reliance economic growth in a given society, sustained over a long time is associated with a substantial reduction in poverty, unemploymentand inequality. Development is a term used to appreciate the need for institutional change from the primitive society to a more advance society in the less develop, least develop and even developing countries of the world [3].
Developing countries [4] are countries of the world that are emerging from a post-traditional mode of production to a more industrialized mode of production. In same similitude, they can be seen as sovereign nations of the world that are in their transition period from a developing economy to a developed economy. They are countries which are in the process of becoming industrialized [5]. Similarly, they are countries whose political, economical, religious, cultural life is not easily influenced by developed countries. In other words, they are countries which are manned with low level of dependence/assistance from the developed countries. Developing countries are countries that are going through the initial levels of industrialization development along with low per capita income [6]. Developing countries of the world include Nigeria, Ghana, Egypt, Argentina, Armenia, Botswana, Cabo Verde, Congo, Comoros, Costa Rica, Egypt, Dominica Republic, Gabon, Grenada and Fiji among others.

Meaning of Business Sector: In Economics, the business sector or corporate sector or simply 'business' is the part of the economy made up by companies [1]. It is a subset of the domestic economy [6], excluding the economic activities of the general 
government of private household, and of non-profit organization serving individuals [7]. Business sector is agglomeration of individualized businesses in an economy that are responsible for providing goods and services with a price tag to a given proportion of people, and in return the people are expected to pay the prices in order to utilize such goods and services. In light of this [8] added that the business sector is the portion of the economy that consist of companies for-profit.
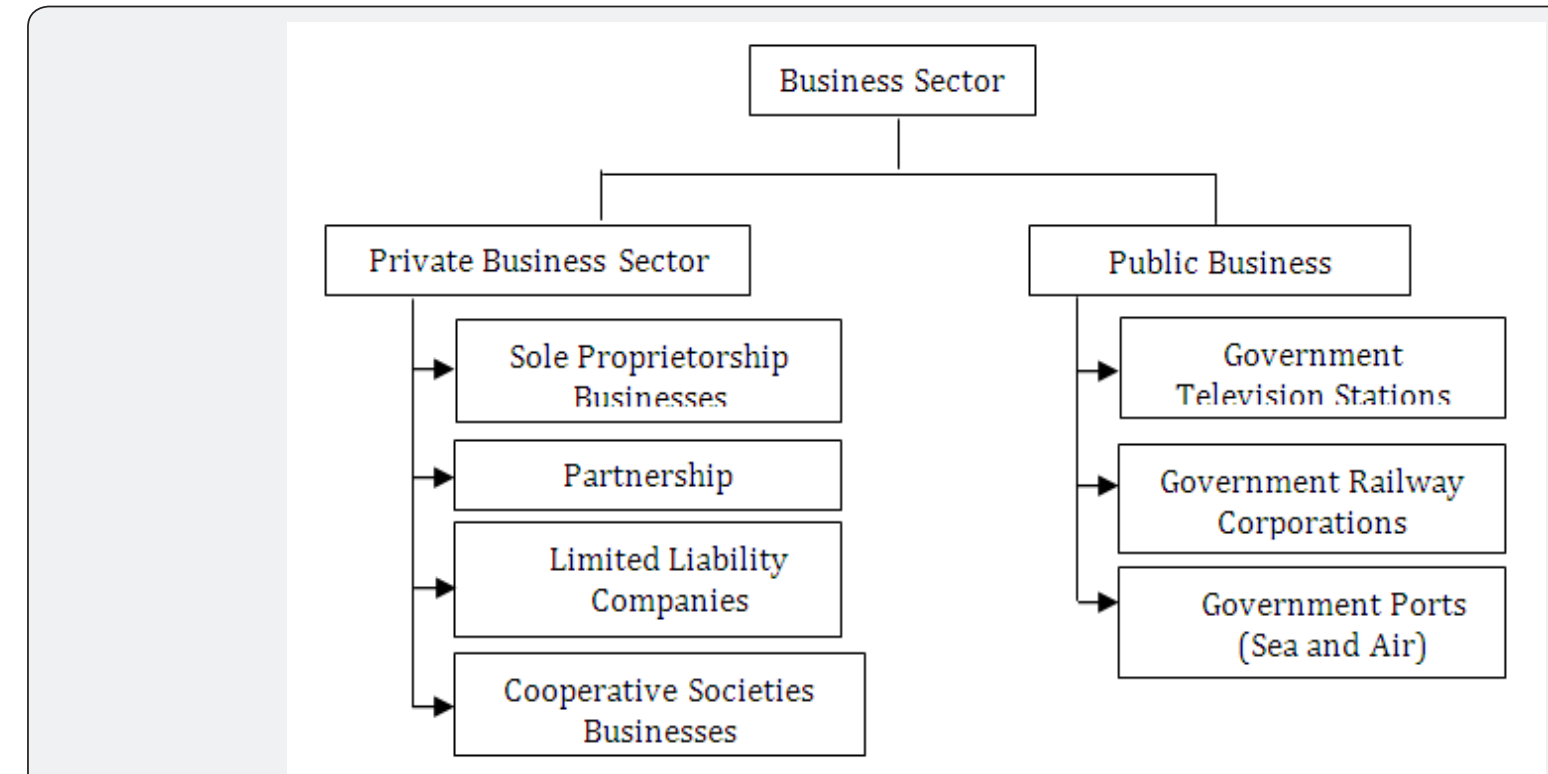

Figure 1: Business sector.

In contemporary time, the meaning of business sector has shifted from the sector that is involved in mostly goods to a more of services oriented. In light of this, the business sector consists of all organizational/institutional set-ups that are geared toward adding values to humanity. These values are worthwhile psychological and physiological in nature, and are desirable by individuals in a particular country, in which they anticipate paying a monetary equivalent in order for them to utilize and in return it adds to the organizations' profit. Business sector can be subdivided into two types (Figure 1).

Private Business Sector: This comprises of all business units of non-governmental organization owned and managed by private individuals with a greater incent zing factor of making profit. In other words, the private business sector generally entails a cluster of business organizations set up for profit motives. Businesses in the private business sector include sole proprietorship businesses, partnership businesses, cooperative societies businesses and limited liability companies.

Public Business Sector: Public business sector comprises of all governmental business organization set-up with less emphases on making profit but rather providing essential services that would helps in increasing the standard of living of its citizens with a little price to be forgo (pay) by the citizens in order to utilize the services or goods. Businesses in the private business sector include government owned television stations, government owned railway corporations and government owned ports (sea and air) among others.

The business sector of a particular nation is often influenced by the forces of demand and supply; government policies, global business activities among others. In developing countries the business sector account for about 26\%-40\% contribution to gross national product. It due to this fact that government of most developing countries often direct their keen interest in improving the sector, in terms of formulating policies that would ensure that the sector thrive and similarly cooperating with relevant stakeholders within the sector.

\section{Concept of Forensic Management}

Forensic management is a novel term in the field of Management. The term 'forensic management' is a compound word which meaning can be farfetched in segmentation of the meaning of the word 'forensic' and 'management'. Forensic relates to or denotes the application of scientific methods and techniques to the investigation of crime [9]. Forensic is related to scientific methods of solving crimes, involving examining the objects or substance that is involved in the crime [10]. The term management may also refer to those people who manage an organization. Management is to forecast, to plan, to organize, to command, to coordinate and control activities of other [11]. Management consists of the interlocking functions of creating corporate policy and organizing, planning, controlling and directing an organization's resources in order to achieve the objectives of the policy [12]. Management (managing) is the administration of an organization, or government body [13]. Management includes the activities of setting the strategy of an organization and coordinating the efforts of its employees (or of volunteers) to accomplish its objectives through the application of available resources, such as financial, natural, technological, and human resources [14]. 
Forensic management is the application of management skills in the detection of misappropriation, mismanagement, embezzlement of fund and other criminal activities within a given organization. In a concise definition, forensic management is the act, process and science of formulating policies, organizing resources (human and material), planning the success of an organization, controlling the resources and directing the resources of the organization, with the purpose of surfacing/ preventing crime and other fraud related issues so as to increase aggregate productivity in the organization. It can also be simply seen as the adoption of managerial approach to the investigation of fraud related affairs in any organizational set-up, which will in the long-run pave way for subsequent hindrance to the occurrence of mismanagement, misappropriation and other managerial/financial crime related act among staffs/personnel's of a given organization. Forensic management can be done at two major levels

Individual Level: Forensic management at individual level involves a staff/worker of a particular organization ensuring that on his/her part does not involve in any fraudulent or criminal related financial misconduct while handling the day-to-day activities of an organization. The notion behind individualized forensic management is that, an employee is employ for a given task of ensuring effective/efficient actualization of a given set goal in an organization, which must be free from fraud related issues from the employee.

Collective Level: Collective level simply means a cooperative effort of every staffs in a given organization directing their effort in order to achieve criminal and fraud free activities in the organization. This often consists of a collective effort of top, middle, bottom managers and subordinate staffs in running an organization with high level of managerial decency of no fraud.

Benefits of Forensic Management in the Business Sectors of Developing Countries

The benefit of forensic management in business sector cannot be overemphasis in developing countries. These benefits include the following.

Detection of Fraud: According to [15], fraud is an intentional misrepresentation of financial information by one or more individuals among management, employees or third parties. Detection of fraud involves the use of criminal deception to obtain an unjust or illegal advantage. One pertinent role of forensic management in an organization is the detection of fraud. In the business sector forensic management assist in the detection of fraud and other crime related activities in each individualized businesses in the sector. This is done through managers of these individualized business organization applying forensic skills and competencies in their day-to-day handling of activities which on the aggregate will pave way for effective and thorough investigation or enquiry into fraud related issues.

Managerial Efficiency: Efficiency in carry out a given task is a catalyst for improve productivity in an organization. Forensic management enhances efficiency in the business sector. This is due to the fact that top, middle and low level managers in their bit tend to rid-off the activities of mismanagement and embezzlement of fund in the businesses which they manager. In same similitude, unnecessary bedeviling practices among top management staff to subordinate management staffs in the business sector is remove. This will on the aggregate enhances efficiency in the business sector.

Bridge Communication Gaps: In any organization, communication is an efficient channel of achieving the goals and objectives of the organization. In light of this, in any business organization or enterprise effective communication is a pivotal for the attainment of a particular set goals which the business sought to achieve. Communications gap may be as a result of contract dispute in an organization or more pertinent in organizations were fraud seemed to be at the hems of affair among staffs. In other words, it is due to staffs of a particular business indulgence in criminal acts within a given business organization. Effective forensic management remove such communication barriers in term of bridging the gaps among staffs in a given business organization and on the aggregate the business sector.

Effective and Strong Internal Control: For a given sector of a nation to thrive, it must have a strong internal control. Strong internal control assists to solidify and centralised a given organisation. Forensic management is geared toward a solidified internal control. This strong internal control is achieved through collaborative effort from sub-ordinate staffs with the aim of achieving purposeful forensic management. In other words, forensic management tends to make every units in a given business organisation to be united managerially.

Avoiding of Legal Action: In every field of human endeavour and organisation, avoidance of legal action is always very pertinent. This is due to the fact legal action may retard the growth and development of an organisation. Legal action may involve debt related issues, business asset issues among other. Forensic management is often beneficial due to the role of avoidance of unforeseen or assist a particular business establishment in a legal action. This is as a result of the fact that forensic management tends to take a proactive and meticulous investigation into an organisation and similarly managing the organisation. Sequence to this fact, the business sector will be to a greater level free from unforeseen legal action.

Good Reputation: Good reputation of any organisation is an incentizing factor for investor to make transaction with such organisation. This is due to the fact that no investor will want to invest or enter into any financial transaction with organisation that does not have good reputation. Forensic management assist in raising the reputation of individualized businesses which on the aggregate will raise the reputation of the sector. This will help internationals organisation in rating the high country in which forensic management is practice due to it lantern good reputation that is felt. 
Strategies For Effective Forensic Management In The Business Sectors Of Developing Countries

The following are strategies for effective forensic management to be achieved in the business sector of developing countries.

Education: Education is a catalyst for achieving a particular goals and objectives in a given organization. In a business sector, education involves awareness platform to enlighten staffs of a particular organization or to inculcate certain desirable skills and competencies on them that would assist them to improve on the level of their job performance on aggregate. For forensic management to be achieved its lantern benefits in the business sector of developing countries, there is need for business practitioners and staffs of an organization to be educated on the procedures, rudiments, and ways forensic management works. This will assist staffs in contributing their needed quota in achieving the set purpose for which the forensic management is designed. Similarly, education makes use of awareness programmer, workshops, symposia, seminars, field trips and training among others. Awareness programs such as workshop and symposia involves one form of exhibitions by experts or an expert teaching/lecturing the management staffs and subordinate staffs on the modus operandi of forensic management; while field trips involves visiting some business organization within the sector that are performing productively well with forensic management; similarly, training involves equipping staffs of a given business organization with the needed disposition on how to effectively utilize forensic management process to achieve a set business goal(s). In light of this, [16] submitted that training and guidance is vital in maintaining the effectiveness of the strategy for the detection and prevention of fraud and corruption and its general credibility.

Forensic Management System (FMS): Forensic Management System (FMS) is the hub for the actualization of effective forensic management. The forensic management system is design in a way that would assist managerial staffs and sub-ordinates in tackling/handling crime and fraud related activities in the organization. The forensic management system comprises of persons for forensic management unit, investigation/enquiry unit, assessment/analysis unit, and execution unit. The persons for forensic management unit comprise of subunits in the hierarchy level of management of a particular organization, which is from top managers to subordinate staffs, their function is to ensure the success of the forensic management system. The investigation unit is charged with the responsible of making enquiry or detection of misappropriation case or other form of financial crimes within the organization. The analysis unit is responsible for assessing cases of the extent to which a particular activity is fraud related. Finally the execution unit is vested with the power to disciplining erring staffs found guilty of any fraudulent or financial crime activity within a given organization.

Proper Remuneration of Employees: Proper remuneration of employees is an avenue of intimacy for employees to key in to a particular vision of an organization without any barrier on their part. In other words, proper remuneration of employees is an incent zing factor that assists them to perform their jobs efficiently/effectively and similarly, to be determined to key into any goals which a given employer of labor is set to achieve. Forensic management is achieved to a great extent if and only if the workers/staffs are given their salaries and other accrued benefits as at when due, this will energized them to shun any fraudulent activities within the business organization they are working. Similarly, it will help them not to indulge in any crime related activities of falsification of documents, misappropriation of organizational funds, mismanagement of resources, and embezzlement of funds among other. This will on the long-run pave way for attaining effective forensic management in the business sectors of developing countries.

Partnership and collaboration: Partnershipand collaboration is a network that helps in the actualization of common goals and objectives in any organization. This is due to the fact that, it helps to assist each of the parties that are involved. Partnership and collaboration are effective channels which ideas can be share (ideas, knowledge, and skills) among individual businesses in the sector. In other words, partnership and collaboration are two vital means that tend to improves productivity through shared ideas, knowledge, and skills among others. Effective and efficient forensic management[17] requires partnership and collaboration among different business establishment in the business sector. Partnership and collaboration avail businesses in developing countries of the opportunities to share their skills, competencies, ideas and prior information among other between themselves, so as to effectively/efficiently utilize forensic management in enhancing their businesses in terms of productivity. Similarly, this will helps businesses in the sector to enquire from other businesses were forensic management seems to be very effective and efficient in restructuring the businesses sector to a more advance level.

\section{Conclusions and Recommendations}

The business sector plays a vital role in the pace of economic productivity and national development in any nation, be it developed, developing or less developed. With emphases on developing countries, manning the individualized businesses through forensic management will assist in effective/efficient riding-off fraud and other managerial crime in these businesses which will pave way for productive business sector. In other words, forensic management facilitates in the checkmating misappropriation, mismanagement and other crime issues in the business sector of developing countries. Hence, adopting of forensic management by business enterprise/organization in these developing countries will assist in yielding lantern benefits to a business and on the long-run the business sector and the economy of a nation at large.

In the business sector, each individual business should institutionalized code-of-conduct/strict rules and regulations to govern the conduct of their staffs/workers. This will help 


\section{Annals of Social Sciences \& Management studies}

to detect when an action is fraudulent/criminal or against the business organizations' goal by personnel in the forensic management system (FMS).

Information communication technologies should be adopted in each individualized business and utilized in the day-to-day business activities. This will assist in fast-tracking cases of fraud or other managerial related problems that might arise in the dayto-day business activity.

\section{References}

1. Akarowhe K (2017a) Benchmarks for Business Administration for Sustainable National Development. Arabian Journal of Business and Management Review 7(5): 323

2. Umo JU (1986) An Africa Perspective. John West Publication Ltd, Ikeja, Nigeria p. 23.

3. Akarowhe K (2017b) Information Communication Technology in the Educational System of the Third World Countries as a Pivotal to meet Global Best Practice in Teaching and Development. America Journal of Computer Science and Information Technology 5: 2 .

4. Global EDGE (2009) Developing Countries. International Business terms.

5. (2018) Difference Between Developed Countries and Developing Countries.
6. Keese, Mark, Salou, Gerard, Richardson (1991) The Measurement of Output and Factors of Production for the Business Based. Organization for Economic Cooperation and Development (OECD). Department of Economics and Statistics, Working Paper pp. 95-100.

7. (2008) BLS Information Glossary, US Bureau of Labour and Statistics Division of Information Services

8. (2018) What are the Different Types of Business Sector?

9. (2019) What is Forensic.

10. Cambridge Dictionary (2018) Forensic.

11. Henry Fayol(2018) What is Management.

12. What is Management? Definition and Meaning.

13. (2018) Management: Concepts and Applications.

14. (2018) What is Management?

15. Dandago KI (1997) Fraud Detection and Control at Local Government Level. Journal of the Association of National Accountant of Nigeria 7(4).

16. Okoye EI, Gbegi DO (2013) Forensic Accounting: A Tool for Fraud Detection and Prevention in the Public Sector (A Study of Selected Ministries of Kogi State. International Journal of Academic Research in Business and Social Sciences 3(3): 1-19.

17. (2017) What is Forensic. Longman Business English Dictionary.

\begin{tabular}{|l|}
\hline \multicolumn{1}{|c|}{ Your next submission with Juniper Publishers } \\
will reach you the below assets \\
- Quality Editorial service \\
- Swift Peer Review \\
- Reprints availability \\
- E-prints Service \\
- Manuscript Podcast for convenient understanding \\
- Global attainment for your research \\
- Manuscript accessibility in different formats \\
( Pdf, E-pub, Full Text, Audio) \\
- Unceasing customer service \\
Track the below URL for one-step submission \\
https://juniperpublishers.com/online-submission.php \\
\hline
\end{tabular}

